Artikel Penelitian

\title{
Dukungan Keluarga meningkatkan Kepatuhan Minum Obat pada Penderita Tuberkulosis Paru di Kabupaten Tapanuli Utara
}

\section{The Relationship of Family Support with Medication Adherence in Patients with Pulmonary Tuberculosis in West Tapanuli Regency}

\author{
Idawaty Siregar ${ }^{1}$, Parluhutan Siagian ${ }^{2}$, Elmeida Effendy ${ }^{3}$ \\ ${ }^{1}$ Dinas Kesehatan Tapanuli Utara Kabupaten Tapanuli Utara Medan \\ ${ }^{2}$ Departemen Paru Fakultas Kedokteran Universitas Sumatera Utara Medan \\ ${ }^{3}$ Departemen Psikiatri Fakultas Kedokteran Universitas Sumatera Utara Medan
}

\begin{abstract}
ABSTRAK
Salah satu penyakit yang masih menjadi permasalahan kesehatan di dunia termasuk Indonesia adalah tuberkulosis (TB) yang disebabkan oleh kuman Mycobacterium tuberculosis (M. tuberculosis). Keberhasilan pengobatan TB memerlukan kepatuhan penderita dalam minum obat anti tuberkulosis (OAT). Dukungan keluarga seperti pengawasan dan memberi motivasi kepada penderita TB merupakan faktor yang berperan dalam kepatuhan penderita. Penelitian ini dilakukan untuk mengetahui hubungan dukungan keluarga dengan kepatuhan minum obat pada penderita TB paru di Kabupaten Tapanuli Utara. Desain penelitian ini adalah cross sectional dengan responden 60 penderita TB paru kategori 1 dan 2 yang mendapat pengobatan minimal 1 bulan serta tinggal bersama keluarga. Penelitian dilaksanakan di Puskesmas Pangaribuan, Puskesmas Situmeang Habinsaran, dan Puskesmas Hutabaginda di Kabupaten Tapanuli Utara pada bulan Juni-September 2017. Responden diwawancarai dengan menggunakan pertanyaan kuesioner untuk mengumpulkan data. Hasil penelitian ini menunjukkan terdapat hubungan antara dukungan keluarga dengan kepatuhan minum obat pada penderita TB paru di Puskesmas Tapanuli Utara $(p=0,002)$. Pada penelitian ini, dukungan keluarga yang baik meningkatkan kepatuhan penderita TB untuk minum obat anti tuberkulosis (OAT).
\end{abstract}

Kata Kunci: Dukungan keluarga, kepatuhan, tuberkulosis paru

\begin{abstract}
ABSTRAK
One of the diseases that remains a health problem in the world, including Indonesia, is tuberculosis (TB) caused by Mycobacterium tuberculosis (M. tuberculosis). Medication adherence is needed in the success of TB treatment. Family support such as supervision and motivation for TB sufferers are factors relating to patients' adherence. This study was conducted to determine the relationship of family support with medication adherence for pulmonary TB patients in North Tapanuli Regency. This study was a cross-sectional study with a total of 60 respondents of category 1 and 2 pulmonary TB patients who received treatment for at least 1 month and stayed with their family. The study was conducted at Pangaribuan community health center, Situmeang Habinsaran community health center, and Hutabaginda community health center in North Tapanuli Regency from June to September 2017. Respondents were interviewed using questionnaires to collect data. The results showed there was an association between family support with medication adherence of pulmonary TB patients in North Tapanuli Regency $(p=0.002)$. According to this study, good family support can improve adherence to anti-tuberculosis treatment among pulmonary tuberculosis patients.
\end{abstract}

Keywords: Adherence, family support, pulmonary tuberculosis

Korespondensi: Idawaty Siregar. Dinas Kesehatan Tapanuli Utara Kabupaten Tapanuli Utara Medan, JI. Hutatoruan IV, Tarutung, Kabupaten Tapanuli Utara, Sumatera Utara 22411 Tel.081384699488Email: idawatynurlian01@gmail.com

DOI: http://dx.doi.org/10.21776/ub.jkb.2019.030.04.14 


\section{PENDAHULUAN}

Tuberkulosis masih menjadi masalah kesehatan di dunia, khususnya di negara berkembang seperti Indonesia $(1,2)$. Data dari Global Tuberculosis Report tahun 2017 menunjukkan bahwa Indonesia berada pada peringkat kedua penderita tuberkulosis terbanyak dengan perkiraan 1.020.000 kasus, di bawah India (1). Keberhasilan pengobatan TB paru tidak hanya tergantung dari tenaga kesehatan tetapi juga tergantung dari dukungan keluarga $(2,3)$ dan kepatuhan penderita terhadap regimen pengobatan yang diberikan (4). Aspek pengobatan meliputi saran dan perintah yang diberikan oleh dokter atau tenaga kesehatan dilakukan oleh penderita (5), sedangkan dukungan keluarga adalah apabila salah satu anggota keluarga memiliki masalah, maka anggota keluarga lain membantu sehingga memberikan rasa nyaman, diperhatikan, atau dihargai (2).

Penderita TB paru memerlukan pengobatan yang rutin selama 6-9 bulan, bahkan dalam beberapa kasus memerlukan pengobatan yang lebih lama. Hal tersebut menyebabkan penderita TB paru mengalami stres berat dan merasa rendah diri sehingga penderita TB memerlukan dukungan yang kuat untuk meningkatkan kepatuhan minum obat dan harapan hidup penderita (6). Salah satu faktor risiko tidak patuhnya penderita dalam pengobatan adalah tidak adanya dukungan keluarga sehingga perhatian dan motivasi perlu diberikan kepada penderita untuk mendukung keberlanjutan pengobatan $(3,5)$.

Terdapat banyak faktor yang mempengaruhi kepatuhan pengobatan TB diantaranya tentang TB, lamanya pengobatan, transportasi ke pelayanan kesehatan, sosio ekonomi (4,5), karakteristik penderita, dan dukungan sosial yang diterima penderita (5). Penderita TB yang tidak diobati atau tidak patuh dalam pengobatan tidak hanya berisiko terhadap penderita TB itu sendiri, tetapi juga berisiko terhadap masyarakat dan terhambatnya pengendalian TB (7). Beberapa hal yang terjadi apabila tidak patuh dalam pengobatan TB adalah meningkatnya angka kegagalan pengobatan TB, penderita TB paru semakin banyak ditemukan (8), infeksi TB berkelanjutan, kegagalan pengobatan TB, dan meningkatkan terjadinya multi drug resistance (MDR) TB (7). Peran besar yang dapat diberikan untuk meningkatkan kepatuhan penderita TB adalah motivasi dan dukungan dari keluarga seperti pengawasan dan dorongan untuk penderita TB dalam menjalani pengobatannya (8). Laporan penelitian di negara-negara berkembang menemukan bahwa meningkatnya kualitas pelayanan fasilitas kesehatan dan dukungan keluarga pada penderita TB selama pengobatan menyebabkan meningkatnya kepatuhan penderita selama pengobatan TB dan meningkatnya kualitas hidup penderita TB (9). Palinggi et al., melaporkan adanya hubungan antara motivasi keluarga dengan kepatuhan berobat pada penderita TB Paru rawat jalan di RSU A. Makkasau Parepare ( $p=$ value 0,029) (8).

Hasil survei pendahuluan di Dinas Kesehatan Tapanuli Utara menunjukkan penurunan angka kesembuhan dari tahun 2015 sebesar 84,5\% menjadi 68,78\% pada tahun 2016. Angka kesembuhan lebih dari $85 \%$ merupakan salah satu indikator penilaian keberhasilan pengendalian TB. Penurunan angka kesembuhan tersebut kemungkinan disebabkan karena ketidakpatuhan penderita TB dalam menjalani pengobatannya. Hal ini diperkuat dengan hasil deep interview di Puskesmas Tapanuli Utara yang menunjukkan bahwa dari 4 orang yang sedang menjalani pengobatan, 1 orang (25\%) diantaranya sadar akan pentingnya patuh, dan 3 orang $(75 \%)$ cenderung tidak patuh dengan $66,7 \%$ diantarnya memiliki dukungan keluarga kurang baik dan 33,3\% memiliki dukungan keluarga yang baik. Salah satu alasan penderita untuk tidak patuh ialah bahwa suami sebagai keluarga terdekatnya, kurang memberikan dukungan dalam hal pengobatan sehingga rutinitas penderita dalam mengkonsumsi obat dalam sehari tidak terkontrol. Oleh karena itu peneliti tertarik untuk melakukan penelitian hubungan dukungan keluarga dengan kepatuhan minum obat pada penderita TB paru di Tapanuli Utara. Penelitian ini lebih menilai apakah keluarga benar-benar mendukung proses pengobatan penderita baik yang sedang dalam fase intensif maupun fase lanjutan, kategori 1 maupun kategori 2. Penelitian tidak hanya menilai keberadaan keluarga, namun juga dukungan serta kepedulian keluarga yang menjadi salah satu pertimbangan saat penderita akan memulai rencana pengobatan.

\section{METODE}

Penelitian ini adalah penelitian analitik observasional dengan pendekatan cross sectional. Kelaikan etik penelitian ini telah didapatkan dari Komisi Etik Penelitian Kesehatan Fakultas Kedokteran Universitas Sumatera Utara No 783/TGL/KEPK FK USU-RSUP HAM/2016. Penelitian dilakukan di Puskesmas Pangaribuan, Puskesmas Situmeang Habinsaran, dan Puskesmas Hutabaginda di Kabupaten Tapanuli Utara pada bulan Juni sampai dengan September 2017 dengan 60 penderita TB paru kategori 1 atau 2 yang telah mendapat pengobatan minimal 1 bulan, dan tinggal bersama keluarga sebagai responden penelitian.

Pengumpulan data dilakukan dengan menggunakan wawancara terstruktur dengan instrumen kuesioner. Pertanyaan kuesioner dukungan keluarga merupakan adopsi dari kuesioner yang telah digunakan oleh Maulida dengan validitas seluruh pertanyaan valid (nilai Alpha Cronbach=0,934). Kuesioner baku Morinsky Medication Adherence Scale (MMAS) terdiri dari 8 pernyataan yang sudah dialih bahasakan ke dalam bahasa Indonesia digunakan dalam penelitian ini untuk menilai kepatuhan pengobatan. Analisis dilakukan dengan uji Fisher exact test untuk melihat hubungan dukungan keluarga dan kepatuhan minum obat.

\section{HASIL}

Responden pada penelitian ini terbanyak adalah laki-laki $(53,3 \%)$, usia $\geq 46$ tahun $(48,33 \%)$, pekerjaan petani $(61,67 \%)$, dan pendidikan SMA $(41,67 \%)$. Responden penelitian ini hampir semuanya mendapat dukungan keluarga yang baik $(96,7 \%)$ dengan kepatuhan minum juga baik (95\%). Hasil menunjukkan dari 58 penderita dengan dukungan keluarga baik, hampir semua (98,3\%) mempunyai kepatuhan minum obat yang baik juga. Dua penderita dengan dukungan keluarga tidak baik seluruhnya mempunyai kepatuhan minum obat yang tidak baik (100\%). Hasil uji Fisher exact test menunjukkan ada hubungan yang signifikan antara dukungan keluarga dengan kepatuhan minum obat $(p=0,002)$. 
Tabel 1. Hubungan dukungan keluarga dengan kepatuhan minum obat

\begin{tabular}{|c|c|c|c|c|c|c|c|}
\hline \multirow{3}{*}{$\begin{array}{c}\text { Dukungan } \\
\text { Keluarga }\end{array}$} & \multicolumn{6}{|c|}{ Kepatuhan } & \multirow{3}{*}{$\begin{array}{c}\text { Nilai } \\
\text { P }\end{array}$} \\
\hline & \multicolumn{2}{|c|}{ Baik } & \multicolumn{2}{|c|}{ Tidak Baik } & \multicolumn{2}{|c|}{ Total } & \\
\hline & $\mathrm{n}$ & $\%$ & $n$ & $\%$ & $n$ & $\%$ & \\
\hline Baik & 57 & $98,3 \%$ & 1 & $1,7 \%$ & 58 & 100 & \\
\hline Tidak Baik & 0 & 0 & 2 & 100 & 2 & 100 & \\
\hline
\end{tabular}

\section{DISKUSI}

Hasil penelitian ini menunjukkan bahwa sebagian besar pasien mempunyai dukungan keluarga dan kepatuhan berobat yang baik, serta dukungan keluarga berhubungan dengan kepatuhan berobat. Faktor penting pada penyakit kronis seperti tuberkulosis paru adalah dukungan keluarga (10) dan kepatuhan pasien terhadap pengobatan medis yang dijalani penderita (11). Kepatuhan pasien dapat diukur dari cara minum obat yang benar sesuai petunjuk petugas kesehatan seperti jumlah obat dan waktu minum obat (13). Hasil penelitian ini menunjukkan bahwa hampir semua responden mempunyai kepatuhan yang baik dalam meminum OAT (95\%). Penelitian yang dilakukan oleh Siswanto et al di Kota Padang, penelitian Mongan dan Fajar di Kendari dan Paz-Soldan et al., di Peru menunjukkan hasil yang sama dengan penelitian ini $(2,9,13)$. Hasil penelitian ini berbeda dengan laporan WHO tahun 2003 dalam Kristianingrum dan Budiyani yaitu ratarata kepatuhan pasien pada terapi jangka panjang terhadap penyakit kronis di negara maju hanya sebesar $50 \%$, sedangkan di negara berkembang, angka kepatuhan lebih rendah dikarenakan kurangnya tenaga kesehatan dan ketimpangan akses pelayanan kesehatan (15). Kemiskinan, pedidikan rendah, pendapatan negara rendah, diskriminasi ras, merupakan beberapa hal yang menyebabkan terjadinya ketimpangan akses pelayanan kesehatan (18). Beberapa laporan penelitian menunjukkan bahwa banyak faktor yang mempengaruhi kepatuhan pengobatan TB, kurangnya ilmu pengetahuan tentang TB, lamanya pengobatan, kehilangan pekerjaan, kesulitan keuangan, transportasi dan akses ke fasilitas kesehatan, pandangan masyarakat, pengucilan oleh masyarakat, efek samping obat dan makanan tidak bergizi (4).

Kepatuhan penderita sangat diperlukan dalam menjalani pengobatan jangka panjang. Adanya dukungan sosial keluarga telah terbukti menurunkan mortalitas dan meningkatkan kesembuhan penderita TB (14). Pada penderita TB paru kepatuhan meminum obat anti tuberkulosis (OAT) sangat dibutuhkan karena dapat menurunkan kemampuan dan membunuh $M$. tuberculosis dalam tubuh. Data dari Puskesmas Motoboi Kecil tahun 2014 menunjukkan bahwa apabila pasien patuh minum obat maka dapat sembuh hanya dengan pengobatan OAT kategori 1. Sebaliknya apabila kepatuhan minum obat buruk maka penderita TB tersebut akan melanjutkan pengobatan TB ke tahap selanjutnya yaitu pengobatan OAT kategori 2 dan TB dengan multiple drug resistent (MDR) (11).

Kepatuhan penderita dalam minum obat akan meningkat apabila dukungan keluarga yang diberikan kepada penderita juga semakin baik (6) tetapi penderita juga harus memiliki keinginan atau motivasi untuk sembuh
(12). Dukungan keluarga yang baik membuat penderita merasa nyaman dan menambah percaya diri dalam menjalani pengobatannya (2). Dukungan keluarga juga menyebabkan pasien merasa lebih dicintai, diperhatikan, dihormati, dibantu dari sisi ekonomi, dan penderita tidak merasa sendiri tidak terbebani dengan penyakit yang dideritanya (11). Penderita akan merasa bahagia ketika mereka mendapat perhatian, nasehat, dan dukungan dari keluarga, karena memberikan rasa percaya diri untuk menghadapi penyakitnya (2). Dukungan keluarga dapat berupa dukungan sosial, dukungan instrumen, dukungan informasi $(12,13)$ dan dukungan penilaian berupa bimbingan pada penderita (13). Beberapa contoh bentuk dukungan sosial yaitu mengingatkan untuk kontrol berobat, minum obat teratur dan tepat waktu, serta memperhatikan keluhan penderita. Dukungan instrumen dapat berupa dukungan finansial, pengawasan terhadap penderita TB dalam menjalani pengobatan, dan membantu penderita TB paru jika membutuhkan pertolongan. Pemberian informasi kepada penderita untuk meningkatkan sugesti sehingga penderita memahami tentang penyakit TB paru dan pengobatannya merupakan bentuk dukungan informasi $(12,13)$

Hasil penelitian ini mendapatkan bahwa hampir semua responden mendapat dukungan yang baik dari keluarga $(96,7 \%)$. Penelitian ini sejalan dengan laporan penelitian Irnawati et al., yang menunjukkan dalam menjalani pengobatan TB sebagian besar penderita (83\%) mendapat dukungan keluarga (11). Pada penelitian ini, sebagian besar responden sudah berkeluarga sehingga hal tersebut yang memungkinkan semua responden mendapat dukungan keluarga dengan baik dari istri/suami dan anakanaknya. Hal tersebut juga kemungkinan disebabkan karena ada usaha dari keluarga untuk membantu responden dalam keuangan, kasih sayang, perhatian, semangat, dan motivasi. Penelitian yang dilakukan oleh Paz-Soldan et al., di Peru, menunjukkan bahwa hampir semua responden mendapat dukungan keluarga dan petugas kesehatan sehingga secara psikis lebih siap dan termotivasi untuk patuh dalam pengobatan (9). Penelitian DiMatteo dalam Miller dan DiMatteo menunjukkan bahwa kepatuhan minum obat pada penderita yang telah menikah 1,27 kali lebih patuh dibandingkan yang belum menikah karena pasangan mengawasi dan memperhatikan penderita dalam menjalani pengobatannya sehingga perilaku penderita dalam menjalani pengobatan lebih baik (17). Kulkarni et al., melaporkan bahwa penderita yang tidak tinggal dengan keluarganya lebih tidak patuh dalam pengobatan dibandingkan dengan penderita yang tinggal dengan keluarganya (3). Penderita mengharapkan dukungan emosional dan bimbingan dari anggota keluarga inti dan menganggap rumah menjadi surga untuk beristirahat dan proses penyembuhan (16). Peran dan dukungan keluarga sangat penting pada penderita TB paru mulai dari awal terjadinya infeksi sampai akhir pengobatan untuk kesembuhan pasien (15). Keputusan penderita untuk menyelesaikan terapinya atau tidak dipengaruhi oleh dukungan keluarga, pengetahuan penderita tentang TB dan pengobatanya, serta keyakinan penderita terhadap kesembuhan dan pengobatannya (13).

Penelitian ini membuktikan bahwa dukungan keluarga memiliki peran penting bagi penderita TB paru dalam menjalani pengobatannya, akan tetapi terdapat pasien yang walaupun dukungan keluarga tidak baik, kepatuhan pasien juga baik. Hal ini kemungkinan karena penderita 
memiliki motivasi dan keinginan kuat untuk sembuh. Penelitian Muhardiani et al., menemukan bahwa penderita TB yang memiliki motivasi baik memiliki kepatuhan lebih baik (60\%) dibandingkan dengan penderita yang kurang memiliki motivasi (40\%) (19). Disamping itu, kepatuhan pasien meminum obat bukan hanya membutuhkan dukungan keluarga, tetapi juga memerlukan dukungan dari petugas kesehatan,

\section{DAFTAR PUSTAKA}

1. WHO. REPORT: Global Tuberculosis Report 2017. Geneva: World Health Organization; 2017.

2. Mongan R dan Fajar. Relationship between Family Support and Medical Compliance in Patients with Pulmonary Tuberculosis in the Working Area of the Community Health Centerof Abeli: Kendari. Public Health of Indonesia. 2017; 3(1): 17-22.

3. Kulkarni P, Akarte S, Mankeshwar R, Bhawalkar J, Banerjee A, and Kulkarni A. Non-Adherence of New Pulmonary Tuberculosis Patients to AntiTuberculosis Treatment. Annals of Medical and Health Sciences Research. 2013; 3(1): 67-74.

4. Gebreweld FH, Kifle MM, Gebremicheal FE, et al. Factors Influencing Adherence to Tuberculosis Treatment in Asmara, Eritrea: A Qualitative Study. Journal of Health, Population, and Nutrition. 2018; 37(1): 1-9.

5. Rosado-Quiab U, Cedillo-Rivera RM, Cabrera-Gaytan DA, and Vargas-Valerio A. Influence of Family System Characteristics on Adherence to Directly Observed Treatment, Short-Course (Dots) in Pulmonary Tuberculosis-A Cohort Study. Mycobacterial Disease. 2014; 4(5): 1-6.

6. Eyanoer PC. Social Acceptance among Tuberculosis Patients at Puskesmas Amplas Medan, Indonesia. IOP Conference Series: Earth and Environmental Science. 2018;125(1): 1-6.

7. Tesfahuneygn G, Medhin G, and Legesse $M$. Adherence to Anti-Tuberculosis Treatment and Treatment Outcomes among Tuberculosis Patients in Alamata District, Northeast Ethiopia. BioMed Central Research Notes. 2015; 8(1): 1-11.

8. Palinggi $Y$, Kadir AMA, dan Semana A. Hubungan Motivasi Keluarga dengan Kepatuhan Berobat pada Pasien TB Paru Rawat Jalan di RSU A. Makkasau Pare-pare. Jurnal IImiah Kesehatan Diagnosis. 2013; 2(3); 1-8.

9. Paz-Soldan VA, Alban RE, Jones CD, and Oberhelman RA. The Provision of and Need for Social Support among Adult and Pediatric Patients with Tuberculosis in Lima, Peru: A Qualitative Study. BioMed Central Health Services Research. 2013; 13: 1-12.

10. Mayberry LS and Osborn CY. Family Support, Medication Adherence, and Glycemic Control among Adults with Type 2 Diabetes. Diabetes Care. 2012; 35(6): 1239-1245.

11. Irnawati NM, Siagian IET, dan Ottay RI. Pengaruh diantaranya dalam bentuk kunjungan petugas kerumah (21). Dukungan keluarga termasuk keuangan, motivasi, dan dukungan emosional, memiliki pengaruh yang kuat terhadap kepatuhan pengobatan pada penderita TB (12, 20). Dapat disimpulkan bahwa hampir semua penderita TB paru di Puskesmas Tapanuli Utara memiliki kepatuhan yang baik dalam menjalani pengobatannya yang berhubungan dengan kuatnya dukungan keluarga.

Dukungan Keluarga terhadap Kepatuhan Minum Obat Pada Penderita Tuberkulosis di Puskesmas Motoboi Kecil Kota Kotamobagu. Jurnal Kedokteran Komunitas dan Tropik. 2016; 4(1): 59-64.

12. Muna L dan Soleha U. Motivasi dan Dukungan Sosial Keluarga Mempengaruhi Kepatuhan Berobat pada Pasien TB Paru di Poli Paru BP4 Pamekasan. The Journal of Health Sciences. 2014; 7(2): 172-179.

13. Siswanto IP, Yanwirasti, dan Usman E. Hubungan Pengetahuan dan Dukungan Keluarga dengan Kepatuhan Minum Obat Anti Tuberkulosis di Puskesmas Andalas Kota Padang. Jurnal Kesehatan Andalas. 2015; 4(3): 724-872.

14. Susanti ML dan Sulistyarini T. Dukungan Keluarga Meningkatkan Kepatuhan Pasien Diabetes Melitus Di Ruang Rawat Inap RS Baptis Kediri. Jurnal STIKES. 2013; 6(1): 1-10.

15. Samal J. Family Perspectives in the Care and Support of Tuberculosis Patients: An Indian Context. The Jounal of Association of Chest Physicians. 2017; 5(2): 67-69.

16. Sukumani JT, Lebese RT, Khoza LB, and Risenga PR. Experiences of Family Members Caring for Tuberculosis Patients at Home at Vhembe District of the Limpopo Province. Curationis. 2012; 35(1): 1-8.

17. Miller TA and DiMatteo MR. Importance of Family/Social Support and Impact on Adherence to Diabetic Therapy. Diabetes, Metabolic, Syndrome, and Obesity: Targets and Therapy. 2013; 6: 421-426.

18. Pan America Health Organization. Health Determinants and Inequalities. (Online) 2012. http://www.paho.org/salud-en-las-americas2012/dmdocuments/hia-2012-chapter-2.pdf

19. Muhardiani, Mardjan, dan Abrori. Hubungan antara Dukungan Keluarga, Motivasi, dan Stigma Lingkungan dengan Proses Kepatuhan Berobat terhadap Penderita TB Paru di Wilayah Kerja Puskesmas Gang Sehat. Jurnal Mahasiswa dan Peneliti Kesehatan. 2015; 2(3): 17-26.

20. Fagundez G, Perez-Freixo H, Eyene J, et al. Treatment Adherence of Tuberculosis Patients Attending Two Reference Units in Equatorial Guinea. PLOS ONE. 2016; 11(9): 1-13.

21. Safri FM, Sukartini T, dan Ulfiana E. Analisa Faktor yang Berhubungan dengan Kepatuhan Minum Obat Pasien TB Paru Berdasarkan Health Belef Model di Wilayah Kerja Puskesmas Umbulsari, Kabupaten Jember. Indonesian Journal of Community Health Nursing. 2010; 2(2): 12-20. 